University of Nebraska - Lincoln

DigitalCommons@University of Nebraska - Lincoln

2004

TYPE III SECRETION SYSTEM EFFECTOR PROTEINS: Double Agents in Bacterial Disease and Plant Defense

James R. Alfano

Alan Collmer

Follow this and additional works at: https://digitalcommons.unl.edu/plantpathpapers

Part of the Other Plant Sciences Commons, Plant Biology Commons, and the Plant Pathology Commons

This Article is brought to you for free and open access by the Plant Pathology Department at DigitalCommons@University of Nebraska - Lincoln. It has been accepted for inclusion in Papers in Plant Pathology by an authorized administrator of DigitalCommons@University of Nebraska - Lincoln. 


\title{
Type III SeCretion System EfFector ProteIns: Double Agents in Bacterial Disease and Plant Defense
}

\author{
James R. Alfano ${ }^{1}$ and Alan Collmer ${ }^{2}$ \\ ${ }^{I}$ The Plant Science Initiative and the Department of Plant Pathology, University of \\ Nebraska, Lincoln, Nebraska, 68588-0660; ${ }^{2}$ Department of Plant Pathology, Cornell \\ University, Ithaca, New York 14853; email: jalfano2@unl.edu; arc2@cornell.edu
}

Key Words avirulence genes, Hop proteins, $h r p$ genes, hypersensitive response, plant disease

- Abstract Many phytopathogenic bacteria inject virulence effector proteins into plant cells via a Hrp type III secretion system (TTSS). Without the TTSS, these pathogens cannot defeat basal defenses, grow in plants, produce disease lesions in hosts, or elicit the hypersensitive response (HR) in nonhosts. Pathogen genome projects employing bioinformatic methods to identify TTSS Hrp regulon promoters and TTSS pathway targeting signals suggest that phytopathogenic Pseudomonas, Xanthomonas, and Ralstonia spp. harbor large arsenals of effectors. The Hrp TTSS employs customized cytoplasmic chaperones, conserved export components in the bacterial envelope (also used by the TTSS of animal pathogens), and a more specialized set of TTSS-secreted proteins to deliver effectors across the plant cell wall and plasma membrane. Many effectors can act as molecular double agents that betray the pathogen to plant defenses in some interactions and suppress host defenses in others. Investigations of the functions of effectors within plant cells have demonstrated the plasma membrane and nucleus as subcellular sites for several effectors, revealed some effectors to possess cysteine protease or protein tyrosine phosphatase activity, and provided new clues to the coevolution of bacterium-plant interactions.

\section{INTRODUCTION}

Many Gram-negative pathogens of plants and animals possess type III secretion systems (TTSS) that can inject bacterial virulence "effector" proteins into host cells (45). The TTSS is important to the pathogenicity of phytopathogens in the genera Pseudomonas, Xanthomonas, Ralstonia, Erwinia, and Pantoea, bacteria that colonize the intercellular spaces (apoplast) of plants and are generally capable of eliciting plant cell death at some stage in pathogenesis. Most of these pathogens are host specific and have compatible interactions leading to virulence in a limited range of susceptible plant species or cultivars of a species. In resistant 
plants, an incompatible interaction develops, which is marked by the hypersensitive response (HR), a rapid, programmed death of plant cells that occurs at the site of infection and is associated with pathogen avirulence. As discussed below, pathogenesis involves the suppression of basal plant defenses against microbes, evasion or suppression of pathogen-specific HR defense surveillance, parasitic growth in the apoplast, and eventual production of lesions and other characteristic disease symptoms. TTSS mutants fail at the first step in this sequence, and the particular collection of TTSS effectors produced by a strain also are likely to determine compatibility and subsequent patterns of pathogen growth and symptom production. Thus, TTSS effectors are central to the pathogenicity of these bacteria, but how many TTSS effectors do phytopathogens produce? How are these diverse proteins translocated across plant cell walls and plasma membranes? What cellular functions or molecular activities are performed by effectors within host cells? How is the TTSS effector system integrated with other factors involved in plant interactions? These issues are broadly important in molecular plant pathology, and they have attracted far more research than can be covered here. Thus, our review is limited to recent work and examples that are particularly illustrative of the exciting progress that has been made.

We must first explain several terms associated with phytopathogen TTSS effector systems. The TTSS pathway is encoded by hrp ( $\underline{\mathrm{HR}}$ and pathogenicity) and $h r c$ (HR and conserved) genes (23). The Hrc proteins direct secretion of TTSS substrates across the bacterial envelope, whereas a subset of the Hrp proteins (only partially defined) are themselves secreted by the TTSS and direct the translocation of effectors through host cell barriers. The term "effector" denotes the subset of TTSS-substrates that function primarily inside host cells, but some proteins secreted by the TTSS of animal pathogens appear to have multiple roles in promoting effector translocation and acting directly in host cells (45). Because of this ambiguity, we address all proteins shown to travel the Hrp TTSS in this review, including those thought to function primarily as helpers in the delivery of true effectors. Several of the best-studied TTSS effectors are designated as Avr proteins because they were detected through gain-of-function avirulence phenotypes $(86,145)$. Many more effectors subsequently have been identified by their ability to travel the TTSS pathway, and these are designated Hop (Hrp outer protein) in Pseudomonas (4), Xop (Xanthomonas outer protein) in Xanthomonas (118), or Pop (Pseudomonas outer protein, as based on a previous genus designation) in Ralstonia (9).

Terms for different types of resistance also warrant explanation. These are best explained with an example. Pseudomonas syringae pv. glycinea is generally virulent on soybean, but soybean cultivar Harosoy, which carries the Rpg1 R gene shows race-specific resistance to race 1 of $P$. syringae pv. glycinea, which carries the cognate $a v r B$ gene (144). In contrast, all cultivars of soybean show nonhost resistance to $P$. syringae pv. tomato, a pathogen of tomato. Both race-specific and nonhost resistance involve elicitation of the HR, and soybean plants can recognize several effectors produced by $P$. syringae pv. tomato (94). Whether R protein 
surveillance of effectors is the primary determinant of nonhost resistance is unclear $(103,154)$, but similar examples can be found with many pathovars of $P$. syringae and $X$. campestris and affiliated species.

Importantly, plants are universally resistant to nonpathogens, such as Escherichia coli and Pseudomonas fluorescens, as well as to most TTSS-deficient phytopathogen mutants. Nonpathogenic bacteria elicit a defense response not involving the HR, which is variously known as localized induced resistance (51, $93)$, innate immunity $(66,119)$, or basal resistance $(115)$. We use the term basal resistance here. As explained below, we postulate that basal defenses must be suppressed by TTSS effectors before the interaction can progress to either nonhost resistance, race-specific resistance, or compatibility, depending on the plantbacterium combination. A theme of this review is that many of the proteins delivered by the TTSS act as double agents that both elicit and suppress plant defenses.

\section{BASAL AND HR DEFENSES AND PLANT CELL DEATH}

To better understand the functions of TTSS effectors, we must further explain basal and HR defenses. TTSS effectors presumably promote bacterial growth in the apoplast by defeating host defenses and releasing nutrients from plant cells. We can presently distinguish two levels of host defenses that must be defeated. Basal defenses are triggered from the outside of plant cells by nonpathogens, TTSS mutants, heat-killed bacteria, and factors bearing "pathogen-associated molecular patterns" (PAMPs) $(66,111,119)$. These factors are also known as general elicitors, and they represent universal microbial molecules (not pathogen-specific, despite the term PAMP), such as lipopolysaccharide (51), flagellin (66), and cold shock protein (57). Basal resistance appears to be highly localized (hence the alternative term local induced resistance), and many of the same microbial molecules elicit innate immunity in animal cells (111). Basal resistance to nonpathogenic bacteria is manifested in the formation of a callose-rich papilla beneath the plant cell wall at the site of bacterial contact, localized production of reactive oxygen species, and increased expression of phenylpropanoid pathway genes and of other defenseassociated genes (84). Importantly, nonpathogens and PAMPs typically do not elicit the HR, although an exception involving flagellin is discussed below.

In contrast, the HR is elicited inside of plant cells by many phytopathogen effectors during "gene-for-gene" interactions involving matching $a v r$ and R genes (86). The molecular recognition and signal transduction events leading to programmed cell death and the defense of surrounding plant tissues are unexpectedly complex given the two-component genetics underlying race-specific, incompatible interactions. This phenomenon has been the focus of most research on TTSS effectors, as recently reviewed $(109,115)$.

Little is known about the cell death associated with the lesions that develop in later stages of compatible interactions involving virtually all pathogens with a TTSS. In a seminal review of pioneering physiological studies on the HR, Klement 
(91) suggested that "the development of hypersensitive and normosensitive necrosis must be considered as being similar processes; their induction however requires different numbers of bacterial cells and their development proceeds at different rates." Supporting this concept, a recent large-scale mRNA expression profile analysis of Arabidopsis responses to compatible and incompatible strains of $P$. syringae comprehensively documents the overall similarity of the responses, which differ primarily in their timing and suggests that a common signal transduction pathway underlies both (158). In this regard, it is intriguing that plants compromised in the capacity to undergo programmed cell death are unexpectedly more resistant to TTSS-dependent phytopathogens in compatible interactions $(101,148)$.

The multifaceted role of bacterial flagellin in defense elicitation requires further discussion. A conserved domain of approximately 22 amino acids (flg22) in the flagellin proteins of diverse bacterial species elicits defense responses associated with basal resistance (58). Defense elicitation by the flg22 peptide in Arabidopsis is dependent on FLS2, a receptor-like kinase with an extracellular leucine-rich repeat domain, which activates a MAP kinase cascade that increases basal defenses $(12,65)$. However, the flagellins of $P$. syringae pv. tomato and $P$. syringae pv. glycinea can instead elicit the HR in tobacco unless posttranslationally modified by a $P$. syringae pv. tabaci glycosylation system during heterologous expression $(155,156)$. Surprisingly, a flagellin-deficient mutant of $P$. syringae pv. tabaci no longer elicits the HR in nonhost tomato and instead is able to grow and produce lesions similarly to the compatible $P$. syringae pv. tomato (141). These observations suggest that plants may recognize multiple features of flagellins and that defensive recognition of flagellin can be a primary determinant of host range in some pathosystems.

\section{TTSS EFFECTORS: FUNCTIONAL AND COMPARATIVE GENOMICS}

\section{Identifying TTSS Effector Genes in Sequenced Phytopathogen Genomes}

Genome sequencing projects now enable comprehensive identification of TTSS effector genes in individual phytopathogen strains. This is noteworthy because virulence phenotypes of most effectors are too subtle (apparently because of redundancy) to permit identification in collections of random transposon mutants. Thus, identification by avirulence assays involving test plants carrying cognate $\mathrm{R}$ genes has been the historical approach. Genomic sequencing facilitates comprehensive searches based on Hrp promoter activity, on translocation of transposon-generated reporter protein fusions into plant cells, or on sequence patterns associated with Hrp promoters and TTSS targeting domains $(33,41,67,80)$.

Many of the Hrp effector genes are induced in Xanthomonas and Ralstonia by an AraC-type transcriptional activator that is activated by a two-component regulator, 
or in Pseudomonas, Erwinia, and Pantoea by an ECF-type alternative sigma factor that is activated by $\sigma^{54}$-enhancer binding proteins $(4,38,112)$. Genes controlled by these factors have been globally identified by cDNA-AFLP (118), reporter transposons $(59,104)$, or as part of in vitro expression technology (IVET) studies (22). Alternatively, candidate members of Hrp regulons have been identified on the basis of predicted promoter sequences in the complete genomes of $R$. solanacearum GMI1000 (135), X. campestris pv. campestris, X. axonopodis pv. citri (46), and P. syringae pv. tomato DC3000 $(59,179)$. These studies have revealed many genes in each Hrp regulon (in addition to the TTSS machinery genes), but not all of these genes encode TTSS effectors, and some TTSS effector genes are not regulated by the Hrp system.

Recognition of sequence patterns associated with targeting to the TTSS pathway and assays for Hrp-dependent secretion or translocation provide a more direct method for identification of effector genes. TTSS effectors have a modular structure, and targeting information resides in the first 100-150 amino acids (45). The first 15 mRNA codons or amino acids of the P. syringae effector AvrPto are essential, and they may be sufficient for weak translocation of a Cya (adenylate cyclase) reporter $(7,136)$. The remaining $\mathrm{N}$-proximal amino acids contain supplementary targeting information, such that the first 50 amino acids are sufficient for robust secretion or translocation of adenylate cyclase or truncated AvrRpt2 avirulence domain reporters, but maximal secretion or translocation requires the first 100 amino acids $(34,114,136)$.

As discussed below, the secretion/translocation of some effectors is enhanced by customized chaperones, which are expected to interact somewhere between residues $16-150$ of effectors $(5,56)$. Typical $P$. syringae effectors have an hydrophobic amino acid in position 3 or 4 , no acidic amino acids in the first 12 positions, and a bias for serine and proline in the first 50 positions $(41,67,70$, 128). The use of these patterns, along with Hrp promoter sequences, low $\% \mathrm{G}+\mathrm{C}$ content, and other features associated with effector genes, permits facile bioinformatic identification of effector candidates in $P$. syringae genome sequences. However, at least one P. syringae pv. tomato DC3000 effector that lacks these patterns is nevertheless translocated into plant cells by the TTSS, and several Xanthomonas and Ralstonia effectors do not show these patterns at all $(128,136,167)$. Thus, even in well-studied strains such as $P$. syringae pv. tomato DC3000, we cannot yet say that all effector genes have been found.

Nevertheless, over 150 effector genes have been identified collectively in various $P$. syringae strains, and more than 40 TTSS substrates have been experimentally confirmed in the model strain DC3000 $(28,136,167)$. Because of the deluge of information on these proteins, frequently updated, web-based resources are becoming increasingly important in the analysis of the role of effectors in pathogenesis. As one example, http://pseudomonas-syringae.org contains a database on P. syringae pv. tomato DC3000 TTSS substrates and candidates. Included is information on more than 35 features of these proteins, ranging from nomenclature to biochemical activity, as well as links to related databases and other tools for 
functional genomics and genome viewing. Importantly, genomic-based effector inventories are providing new insights into the evolution of the TTSS effector system, and they reveal additional patterns associated with subcellular locations in host cells and the activities of effector families.

\section{TTSS Effector Genes in a Genomic Context}

TTSS effectors are commonly associated with mobile genetic elements, and many appear to have been acquired by horizontal gene transfer $(11,87)$. For example, the $P$. syringae effector genes are associated with regions missing in the related bacteria $P$. aeruginosa and P. putida, and some are carried on plasmids or in hypervariable regions of the genome, such as the exchangeable effector locus $(3,28,36,48)$. In all genomes that have been sequenced to date, the hrp/hrc genes are found clustered in a single region of the chromosome, or on a 2.1-Mb megaplasmid in the case of $R$. solanacearum or a $150-\mathrm{kb}$ plasmid in Pantoea agglomerans (Erwinia herbicola) pv. gypsophilae $(33,107)$. These clusters of $h r p / h r c$ genes are typically flanked by regions that contain different effector genes in different bacterial species or pathovars $(3,33)$. The exchangeable effector locus in $P$. syringae is one such hypervariable region, and another apparent hot spot for effector gene recombination has been identified elsewhere in the $P$. syringae genome $(3,10)$. The use of primers to conserved sequences flanking these hot spots provides another approach to isolating effector genes $(10,36,48)$.

Duplications within genomes of effector genes and associated mobile genetic elements may support ongoing insertions and deletions of effector genes. For example, P. syringae pv. maculicola M6 carries two copies of avrPphE. One is on a plasmid, and the other is on the chromosome and is a site for integration of the plasmid, which carries at least one other effector gene (133). Loss of gene function also may be important in the evolution of virulence (124). Several candidate effector genes in DC3000 are disrupted by mobile genetic elements $(28,67)$; the truncated product of two such genes can be translocated into plant cells by the $P$. syringae TTSS (136); frameshifted effector pseudogenes have been found in the exchangeable effector loci of several $P$. syringae pathovars $(36,48)$; and many effector genes have limited distribution among pathovars and races of $P$. syringae and $X$. campestris and affiliated species.

The taxonomic distribution patterns of effector genes have yielded only tantalizing hints regarding the determination of host and tissue specificities. For example, comparison of the known effectors in X. campestris pv. campestris (a xyleminvading pathogen of crucifers) and $X$. axonopodis pv. citri (a mesophyll-limited pathogen of citrus) revealed the striking absence of members of the AvrBs3 family in X. campestris pv. campestris (46). Members of this effector family are found in several other xanthomonads and in $R$. solanacearum (but not in P. syringae) (28, $96,135)$. There are other interesting distribution patterns involving well-studied effectors. AvrBs 2 homologs are widespread in X. campestris pathovars and affiliated 
species, but they are absent from $P$. syringae, whereas the opposite is observed with AvrE. In contrast, members of the AvrPphE, AvrPphF, and AvrRxv/YopJ families are widespread in both groups, and the latter family is also found in many animal pathogens $(28,46,96)$.

TTSS effectors are likely to be important determinants of host specificity in the $P$. syringae and $X$. campestris groups. However, the TTSS machinery itself may have little role in host specificity, as indicated by the ability of a $P$. syringae pv. tomato $\Delta h r p / h r c$ mutant expressing the $h r p / h r c$ gene cluster of a bean pathogenic P. syringae pv. syringae strain to retain normal virulence on tomato and avirulence on bean (60). The relationship between effector inventories and host range in $P$. syringae is still obscure. For example, analysis of the presence or absence of 12 TTSS effectors in $60 P$. syringae strains from various pathovars revealed no correlation with the host of isolation (69). One explanation for this observation is that allelic variations in effectors that are present in many (or all) pathovars are important determinants of host specificity (147). Importantly, an example of host range limitation by a single TTSS effector has recently been reported: PthG in Pantoea agglomerans pv. gypsophilae appears to be the sole factor preventing this gypsophila pathogen from expanding its host range to beet (55).

\section{TTSS EFFECTOR DELIVERY: SPECIALIZATIONS FOR PHYTOPATHOGENS}

\section{Cytoplasmic TTSS Chaperones}

TTSSs in animal pathogens are dependent on molecular chaperones for the secretion of a subset of secreted proteins $(56,125,165)$. Chaperones share little sequence similarity with each other, but they have the general characteristics of being small (circa $15 \mathrm{kDa}$ ), acidic (isoelectric points $<6$ ), and with a predicted amphipathic region in their $\mathrm{C}$ termini. Also, their encoding gene is often next to the cognate effector gene (166). TTSS chaperones have been separated into classes based on whether they interact with one effector or multiple effectors (or other TTSS-secreted proteins) and whether they function in pathogenic TTSSs or in the flagellar biogenesis TTSS $(42,125)$. TTSS chaperones act in the cytoplasm to stabilize or prevent association of effectors before delivery (123), to maintain effectors in a secretion competent nonglobular state (146), and in some cases to regulate the TTSS (61). The role of chaperones in targeting effectors to the TTSS pathway is still unresolved, and the chaperone-binding domain within a secreted protein may constitute a second secretion signal (40), which acts independently of signals in the first 15 amino acids or mRNA codons of the effector $(8,143)$. TTSS chaperones in Salmonella typhimurium were shown to provide specificity to effector secretion signals, such that in the absence of cognate chaperones, effectors were inappropriately secreted through the flagellar TTSS (99). Importantly, TTSS chaperones may affect the order of secretion of TTSS effectors, allowing a hierarchy of effector delivery $(25,159)$. Indeed, in the Yersinia TTSS, the effectors that 
are predicted to be needed early in pathogenesis to inhibit phagocyotosis utilize chaperones for their secretion $(43,56)$.

TTSS chaperones in phytopathogens were demonstrated only recently, partly because many of the effectors identified by gain-of-function avirulence phenotypes are not associated with chaperones. ShcA (specific $\underline{H}$ op chaperone) from $P$. syringae pv. syringae 61 assists in the secretion of the HopPsyA effector (163). Similarly, the E. amylovora $\mathrm{DspB} / \mathrm{F}$ chaperone is required for secretion of DspA/E (64). Several other candidate $P$. syringae type III chaperones have been identified $(28,163,167)$. Three of these candidate chaperones, ShcM, ShcV, and ShcF, recently have been confirmed to act as chaperones for the effectors HopPtoM, HopPtoV, and HopPtoF, respectively $(17,137,167)$. Moreover, database searches and genome projects have identified several other candidate chaperones in $P$. syringae $(28,70,163,167)$. TTSS chaperones have yet to be demonstrated in $R$. solanacearum, $X$. campestris, or $X$. axonopodis, although genome sequences are available $(46,135)$. Because there is evidence that chaperones help effectors compete for access to TTSSs, the identification of phytopathogen chaperones may reveal which effectors are translocated first into the plant cell and thus lead to a better understanding of the early stages of plant pathogenesis.

\section{Extracellular TTSS Pathway Proteins}

The Hrc proteins enabling effector transport across the bacterial envelop are broadly conserved in the TTSSs of plant and animal pathogens and in the flagellar biogenesis system (21). In contrast, extracellular components of the TTSS machinery are more specialized and variable because of their interactions with host cell barriers. However, these extracellular proteins appear to perform similar functions in all phytopathogens and can be divided into three classes: Hrp pilus subunits, harpins, and translocator factors (the latter defined here as forming a TTSS delivery pore in the host plasma membrane) (30). The pilus proteins and harpins are secreted in particular abundance by phytopathogen TTSSs in culture. All phytopathogens appear to produce a Hrp pilus, which serves as a conduit for effector delivery, as recently reviewed (72). The narrow external diameter $(8 \mathrm{~nm})$ of the Hrp pilus is consistent with its expected role in delivering effectors through the plant cell wall matrix and suggests that most effectors enter the host cytoplasm in an unfolded state.

Harpins have yet to be shown to have any role in effector delivery, and they have been studied primarily for their ability to elicit plant defenses. However, many properties of harpins point to an interaction with the plant cell wall and plasma membrane, which invites the hypothesis that they are helpers in effector delivery. Harpins differ from other proteins secreted via the Hrp TTSS by their defining properties of being glycine-rich, cysteine-lacking, and possessing heatstable HR elicitor activity when infiltrated at relatively high concentrations into the leaf apoplast of tobacco and several other plants. Importantly, harpins differ from true effectors in showing no apparent relationship between elicitor activity 
and host range, and they elicit the HR from the outside rather than the inside of plant cells $(129,157)$.

Harpin-like proteins have been reported in all genera of phytopathogens that have a TTSS $(2,4)$. These proteins include the Hpa $1 / \mathrm{HpaG}$ family in Xanthomonas (176), which was recently shown to have HR elicitor activity (89). Some pathogens produce multiple harpins. For example, Erwinia amylovora and $P$. syringae were previously shown to produce two harpins each, HrpN/HrpW and HrpZ/HrpW, respectively $(37,88)$. HrpW is the prototype for a subclass of harpins that have an apparently bifunctional, two-domain structure. The N-terminal domain is particularly glycine-rich, whereas the $\mathrm{C}$-terminal domain shows similarity to pathogen pectate lyases $(37,88)$. Analysis of the complete genome sequence of $P$. syringae pv. tomato DC3000 revealed the presence of two additional harpins with a twodomain structure similar to that of $\mathrm{HrpW}$ (28). The C-terminal domains of these proteins, HopPtoP and $\mathrm{HopPmaH}_{\mathrm{Pto}}$, are similar to lytic transglycosylases and pectin lyases, respectively, and both show heat-stable HR elicitor activity when infiltrated into tobacco (A.R. Ramos \& A. Collmer, unpublished).

The similarities of HrpW and $\mathrm{HopPmaH}_{\mathrm{Pto}}$ with pectic enzymes, and the observed ability of HrpW to bind specifically to pectate lyase (37), argue for a site of action in the plant cell wall. Furthermore, the higher conservation of the pectate lyase domain among HrpW homologs suggests that this domain has a biologically important interaction with pectic polymers (35), which notably control porosity of the cell wall (18). Harpins are secreted through the Hrp pilus and accumulate along the length of the growing structure $(82,83,100)$, which would be consistent with a role in assisting pilus penetration through the cell wall matrix or in forming a pore upon pilus contact with the plasma membrane. Indeed, purified HrpZ harpin of $P$. syringae pv. phaseolicola can stably associate with liposomes and form pores in synthetic lipid bilayers, which suggests such a role in translocation of effectors across the plasma membrane (98).

The E. amylovora $\mathrm{HrpN}$ harpin elicits defenses through the systemic acquired resistance pathway $(149,168)$, and its activity is dependent on salicylic acid, NPR1/NIM1, NDR1, and EDS1 (50, 127), which suggests that harpins elicit plant defenses through the same signal transduction pathways that are activated by Avr effectors (with the latter differing among each other regarding requirements for NDR1 and EDS1). A consequent puzzle is why harpins produced by biotrophic pathogens, such as E. amylovora, $P$. syringae, and $R$. solanacearum, do not trigger the HR and avirulence during pathogenesis, given that their hosts are hypersensitive to the harpins they produce (129). The explanation may reside in dosage or in suppression of HR defenses by effectors that are injected into host cells. Evidence for either explanation can be found in the delayed expression of the PopA harpin-like protein by wild-type $R$. solanacearum during infection and the avirulence triggered by engineered strains that express PopA constitutively (85). Similarly, the responses of Nicotiana benthamiana leaves to the differing levels of the $P$. syringae pv. phaseolicola HrpZ harpin produced by bacteria, by transgenic plants, or by PVX expressing harpin with a signal peptide suggest that levels far 
higher than that produced by bacteria during infection are needed to elicit the HR (157). Although direct comparisons are difficult because harpins and injected Avr effectors operate outside and inside of plant cells, respectively, the latter proteins appear to trigger the HR at far lower levels and clearly can do so during natural infections.

The translocation of TTSS effector proteins into host cells requires TTSSsecreted accessory proteins called translocators, which form pores in the eukaryotic plasma membrane. These have been extensively characterized in several animal pathogens $(30,45)$. Less is known about TTSS translocators in plant pathogens. However, recent evidence suggests that $\mathrm{HrpF}$ acts as a translocator in $X$. campestris (32, 134). HrpF shares similarity with P. syringae HrpK, Rhizobium NolX, and $R$. solanacearum PopF1/F2, and $P$. syringae hrpK mutants have phenotypes consistent with this protein functioning as a translocator in the $P$. syringae TTSS (T. Petnicki-Ocwieja, K. van Dijk \& J.R. Alfano, unpublished). Clearly, much more research is needed to understand how these proteins interact with other components of the TTSS, how they promote effector translocation across the host plasma membrane, and how plants defend themselves against this prokaryotic violation. In this regard, it is noteworthy that the Yersinia YopB translocator factor can elicit innate immune defenses in epithelial cells unless these responses are suppressed by multiple injected Yop effectors (164).

\section{TTSS EFFECTOR FUNCTIONS}

\section{Effectors and Suppression of Plant Defenses}

The Hrp systems of $P$. syringae and $X$. campestris were implicated in the suppression of basal defenses long before these systems were shown to deliver effector proteins. Lindgren and colleagues showed that defense-related transcripts were induced in bean by avirulent $P$. syringae, saprophytes, and a $P$. syringae hrp mutant, but not by virulent Hrp-proficient $P$. syringae, which suggested that the Hrp system suppressed basal defenses $(77,78)$. Mansfield and colleagues then showed that saprophytes and hrp mutant pathogens induced regions of thickened plant cell wall called papillae at contact points between bacterial cells and the plant cell, which were not induced by virulent wild-type pathogens $(20,27)$.

There were also early clues that some Avr proteins might suppress, as well as elicit, HR defenses. For example, coexpression of cloned avrRpt 2 and avrRpm1 genes in P. syringae pv. tomato DC3000 or P. syringae pv. maculicola M4 revealed that AvrRpt2 was able to interfere with the elicitation of the characteristically fast HR that is normally elicited by AvrRpm1 (in contrast to the slower HR elicited by AvrRpt2) in Arabidopsis ecotype Columbia (131, 132). The concept that some effectors might be HR suppressors was crystallized by the discovery that effector gene mutations in $P$. syringae pv. phaseolicola "unmasked" cryptic Avr activity within a virulent strain, suggesting that the disrupted effector suppressed an HR that would otherwise be triggered by one or more of the effectors in that strain 
$(76,160)$. These papers provided evidence that AvrPphF, AvrPphC, and VirPphA blocked the HR, but they left open the possibility that the suppressors were acting in the bacterial cell by altering gene expression or effector access to the TTSS $(76,160)$. Suppressor activity inside plant cells was established with the demonstration that AvrPtoB (in the same effector family as VirPphA) could suppress HR processes dependent on two R genes, Pto and $C f 9$, when delivered with an Agrobacterium-mediated transient expression system in $N$. benthamiana (1). Figure 1 presents a conceptual overview of TTSS effectors functioning as both elicitors and suppresssors of plant defenses.

Activated plant defense systems express many physiological responses, including the HR, pathogenesis-related (PR) gene expression, phytoalexin production, generation of reactive oxygen and nitrogen species, and callose deposition in the cell wall (47). HR assays are particularly easy to score and have revealed that the $P$. syringae pv. tomato DC3000 effectors AvrPphE $\mathrm{Pto}_{\mathrm{Pto}}$, AvrPpiB1 $1_{\mathrm{Pto}}, \mathrm{AvrPtoB}$, AvrRpt2, HopPtoD2, HopPtoE, HopPtoF (an AvrPphF homolog), and HopPtoN can suppress an HR induced by other test Avr proteins (1, 14, 26, 53, 79, 102, 105). These observations suggest that approximately one third of the effectors in DC3000 have HR suppressive activity, and the use of Agrobacterium or PVX-mediated transient expression systems and mixed inoculum involving two TTSS-proficient bacteria in various experiments demonstrated that suppression in all cases tested is occurring inside plant cells $(53,79)$. Interestingly, several of the effectors are able to suppress a programmed cell death response induced by the pro-apoptotic mouse protein Bax and other elicitors in yeast $(1,79)$. The ability of these effectors to suppress different types of programmed cell death in different organisms suggests that they act on conserved pathways.

Do the effectors that suppress the HR suppress other markers of plant defense? At least in some cases, TTSS effectors appear to be suppressing PR genes (39, 79) and the oxidative burst (26). Notably, HopPtoD2 suppresses a nonhost HR and an HR-like response that is induced by transient expression of an active MAP kinase kinase (MAPKK) in tobacco. The latter is known to be involved in defense pathways, thus suggesting that HopPtoD2 acts downstream of this MAPKK (53). This is interesting because this MAPK pathway has been shown to be activated in response to a number of elicitors of defense responses, and a homologous MAPK pathway in Arabidopsis is activated upon recognition of the flagellin PAMP (12, 174). These observations suggest that HopPtoD2 acts at a point of convergence in defense signal transduction pathways to suppress both host-specific defenses triggered by Avr proteins and basal defenses triggered by PAMPs. Importantly, the P. syringae effectors, AvrPto and AvrRpt2, when expressed in transgenic Arabidopsis, supported increased growth of TTSS-defective P. syringae mutants (39, 71). Moreover, transgenic plants expressing AvrPto had reduced callose deposition and expression of genes encoding secreted or defense-related proteins when challenged with a TTSS-defective mutant compared to wild type Arabidopsis (71). These phenotypes suggest that AvrPto and AvrRpt2 have the ability to suppress PAMP-triggered basal defenses. 


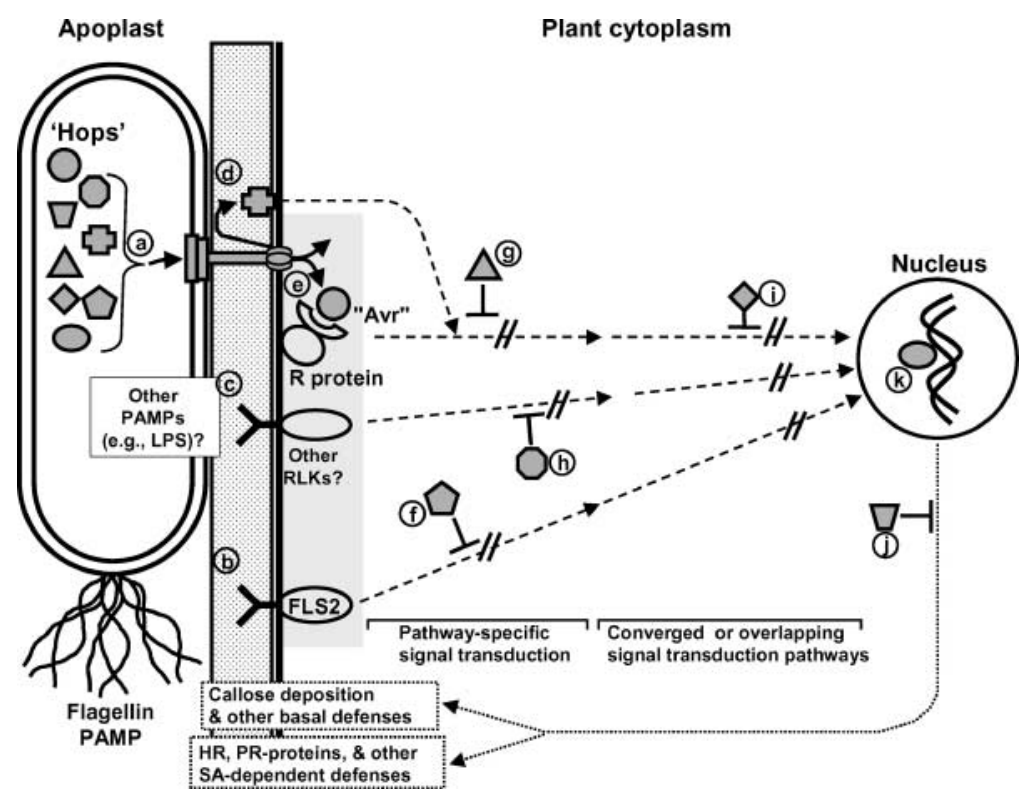

Figure 1 Model depicting sites of action for bacterial TTSS effectors as both elicitors and suppressors of plant defense. (a) Over 30 effectors may be injected into host cells by the TTSS of the model pathogen P. syringae pv. tomato DC3000. (b) P. syringae flagellin activates basal defense pathways following recognition by the FLS2 receptorlike kinase. (c) Other bacterial PAMPs may be recognized by additional receptor-like kinases (RLKs). (d) The TTSS-secreted harpins act in the apoplast and can trigger HR/SAR defense responses from outside of plant cells. (e) A subset of TTSS effectors (i.e., Avr proteins) are recognized inside plant cells by $\mathrm{R}$ proteins, which, according to the guard hypothesis, detect the activities of effectors on "guarded" susceptibility targets and activate HR defenses. The shaded box encompassing the R-protein and basal defense receptors denotes the potential relationship between guarded effector targets, the basal defense system, and the plant membrane, possibly in recognition complexes. Putative sites of action for defense-suppressive TTSS effectors include pathwayspecific components for basal defenses $(f$ and $h$ ) and HR defenses $(g)$. Additional sites of action may be at points where signal transduction pathways converge $(i)$. Antimicrobial responses activated by defense-signaling pathways (or involving preformed factors) also may be inhibited posttranscriptionally $(j)$. And finally, TTSS effectors, such as AvrBs3 family members may act within the nucleus to alter host transcription $(k)$.

As of yet, TTSS effectors that function as defense suppressors have not been described for any bacterial phytopathogens other than $P$. syringae. However, NolP from Rhizobium sp. NGR234 was shown recently to suppress induction of PR genes in tobacco, suggesting that one role of the TTSS in symbiotic rhizobia may be defense suppression (19). Furthermore, although the majority of animal 
pathogen TTSS effectors appear to target primarily actin polymerization to alter phagocytosis, several effectors also suppress proinflammatory defense responses induced by innate immunity in animals $(6,44,120,164,173)$. Thus, it is likely that the suppression of host defenses is a universal function of pathogen TTSSs.

\section{Enzymatic Activities of Effectors}

We have had clues to the enzymatic activities of a few Avr proteins for some time. For example, the $P$. syringae AvrD produces syringolides that elicit the HR in cultivars of soybean with race-specific resistance to races carrying avrD (86, 113). However, we do not know how this contributes to $P$. syringae virulence and whether AvrD can be translocated by the TTSS and produce syringolides within plant cells in addition to its known ability to produce the elicitor in bacterial cells. The X. campestris AvrBs2 shares similarity with Agrobacterium tumefaciens agrocinopine synthase and E. coli glycerophosphoryl diesterase UgpQ, suggesting that AvrBs2 may make or break phophodiester linkages in plant cells (152). Also, much has been learned about the large AvrBs3 family of effectors present in many xanthomonads $(29,96)$. The AvrBs3 family effectors are nuclear-localized (161, $172)$, can act as transcriptional activators $(177,178)$, and have been shown to alter transcription in plants (108). Moreover, expression of AvrBs3 family members in planta causes cell enlargement and hypertrophy of plant cells $(52,108)$.

The rapid increase in the TTSS effector inventory supports new insights into function based on recognition of motifs that predict enzymatic activities and plant targets, as recently reviewed $(31,35,74)$. An emerging lesson is that many effectors appear to be cysteine proteases (Table 1). One large effector family is the YopJ/P/AvrBsT family of ubiquitin-like cysteine proteases, which is made up of proteins belonging to the CE clan of cysteine proteases, as defined by the MEROPS database (http://merops.sanger.ac.uk/) $(120,122)$. The Yersinia YopJ/P effector was shown to inhibit MAPK pathways and the $\mathrm{NF} \kappa \mathrm{B}$ pathway in a manner that was dependent on the active site of the YopJ/P protease $(121,122)$. This results in the suppression of mammalian innate and adaptive immune systems. This family of cysteine proteases appears to be widespread in TTSS-containing phytopathogens and includes representatives in P. syringae (AvrPpiG1, HopPmaD, and HopPsyV) $(3,10,48,70), X$. campestris (AvrRxV, AvrBst, AvrXv4, XopD, and XopJ) (73, $117,118,122,169)$, E. amylovora (ORFB, Acc. No. AAF63400), R. solanacearum (PopP1 and PopP2) (49, 97), and likely others. These proteins are predicted to modify signal transduction pathways by removing SUMO (small ubiquitin-like modifier) modifications from components of defense pathways (122).

In an exciting recent advance, XopD was shown to act on SUMO-modified plant proteins, but not SUMO-modified animal proteins, making XopD the first protein of this class with demonstrable protease activity, although the specific plant target(s) remains unknown (73). In another exciting advance, a plant target may have been identified for the PopP2 protease. This bacterial protein was shown to interact 
TABLE 1 Bacterial plant pathogen TTSS effectors: location in plant and enzymatic and defense suppressor activities

\begin{tabular}{|c|c|c|c|}
\hline Effector $^{\mathrm{a}}$ & Enzymatic activity $^{\mathbf{b}}$ & Suppression phenotype & Location $^{c}$ \\
\hline \multicolumn{4}{|l|}{ P. syringae } \\
\hline AvrB & $\begin{array}{l}\text { RIN4 phosphorylation } \\
\text { (105) }\end{array}$ & ND & PM (116) \\
\hline AvrD & $\begin{array}{l}\text { Syringolide synthase } \\
\text { (113) }\end{array}$ & ND & ND \\
\hline AvrPphB & $\begin{array}{l}\text { Cysteine protease; } \\
\text { cleaves PBS1 } \\
(139,140)\end{array}$ & ND & PM (116) \\
\hline AvrPphC & ND & Masks resident Avr activity (160) & ND \\
\hline AvrPphE $E_{\text {Pto }}$ & ND & $\begin{array}{l}\text { HopPsyA-dependent HR; PR1a } \\
\text { expression; Bax-induced } \\
\text { PCD in plants and yeast (79) }\end{array}$ & ND \\
\hline AvrPpiB ${ }_{\text {Pto }}$ & ND & HopPsyA-dependent HR (79) & ND \\
\hline AvrPto & ND & $\begin{array}{l}\text { Callose deposition; increased } \\
\text { growth of TTSS mutant in } \\
\text { transgenic plants expressing } \\
\text { AvrPto (71) }\end{array}$ & PM (138) \\
\hline $\begin{array}{l}\text { AvrPtoB } \\
\text { (VirPphA) }\end{array}$ & ND & $\begin{array}{l}\text { HopPsyA- and AvrPto-dependent } \\
\text { HR; Bax-induced PCD in plants } \\
\text { and yeast; } \mathrm{H}_{2} \mathrm{O}_{2} \text {-induced PCD in } \\
\text { yeast (Masks resident Avr activity) } \\
(1,76,79)\end{array}$ & ND \\
\hline AvrRpm1 & $\begin{array}{l}\text { RIN4 phosphorylation } \\
\text { (105) }\end{array}$ & ND & PM (116) \\
\hline AvrRpt2 & $\begin{array}{l}\text { Cysteine protease; } \\
\text { eliminates RIN4 } \\
(14,15,106)\end{array}$ & $\begin{array}{l}\text { AvrRpm1-dependent HR }(131,132) \text {; } \\
\text { growth of TTSS mutant in } \\
\text { transgenic plants expressing } \\
\text { AvrRpt2 (39) }\end{array}$ & PM (15) \\
\hline HopPtoD2 & $\begin{array}{l}\text { Protein tyrosine } \\
\text { phosphatase }\end{array}$ & $\begin{array}{l}\text { Nonhost HR; MAPK-induced } \\
\text { HR; PR1 expression; oxidative } \\
\text { burst }(26,53)\end{array}$ & ND \\
\hline HopPtoE & ND & $\begin{array}{l}\text { HopPsyA-dependent HR; PR1a } \\
\text { expression; Bax-induced PCD } \\
\text { in plants and yeast (79) }\end{array}$ & ND \\
\hline $\begin{array}{l}\text { HopPtoF } \\
\text { (AvrPphF) }\end{array}$ & ND & $\begin{array}{l}\text { HopPsyA-dependent HR; PR1a } \\
\text { expression; Bax-induced PCD } \\
\text { in plants and yeast (Masks } \\
\text { resident Avr activity) }(79,160)\end{array}$ & ND \\
\hline HopPtoN & Cysteine protease & $\begin{array}{l}\text { HopPsyA-dependent HR; reduces } \\
\text { resident lesion formation activity } \\
\text { in host (102) }\end{array}$ & ND \\
\hline
\end{tabular}


TABLE 1 (Continued)

\begin{tabular}{llll}
\hline Effector $^{\mathbf{a}}$ & Enzymatic activity $^{\mathbf{b}}$ & Suppression phenotype & Location $^{\mathbf{c}}$ \\
\hline R. solanacearum & & & \\
PopB & ND & ND & N (68) \\
PopP2 & ND & ND & N (49) \\
X. campestris & & & \\
and oryzae & & ND & \\
AvrBs3 & Transcriptional & & N (161, \\
effector family & activator (153, 177) & ND & $172,177)$ \\
XopD & Cysteine protease (73) & ND & N (73) \\
AvrXv3 & Transcriptional activator & ND & ND \\
& $(13)$ & & ND \\
\hline
\end{tabular}

${ }^{\mathrm{a}}$ Effector list only includes effectors for which experimental data supports their activities and/or their location inside plant cells.

${ }^{\mathrm{b}}$ Enzymatic activities listed need not be direct. For example, RIN4 phosphorylation by AvrRpm1 and AvrB is not known to be direct.

${ }^{\mathrm{c} B a c t e r i a l}$ plant pathogen effectors have been localized to either the plant plasma membrane (PM) or the nucleus (N).

ND denotes not done.

with an unusual TIR-NBS-LRR R protein, RRS-1, which contains a WRKY transcription factor domain (49). WRKY transcription factors are commonly utilized during plant defense (54). Thus, the WRKY transcription factor may be the actual virulence target, but since this factor is also involved in recognition of PopP2 in resistant plants, it is unclear whether RRS-1 is a protein targeted by the bacterium to promote disease or a plant receptor for plant defense, or both. This is one of the few examples of an NBS-LRR R protein interacting directly with an Avr protein from a pathogen and has implications for models of how $\mathrm{R}$ proteins recognize Avr products, as discussed below.

Another large family of TTSS effectors shared between plant and animal pathogens is the YopT/AvrPphB family of cysteine proteases, which belong to the C58 family of cysteine proteases $(75,140)$. Interestingly, a member of this family has not been identified in xanthomonads, whereas several have been identified in P. syringae, including AvrPphB (130), AvrPpiC2 (130), HopPtoC (128), and HopPtoN (102) and one in R. solanacearum (RSc3212) (135). YopT was shown to target the RhoA GTPase and cleave a prenyl group from the C-terminal end of RhoA, releasing it from the mammalian plasma membrane and disrupting actin polmerization, and thus preventing phagocytosis by macrophages $(75,140$, 142). In an important advance, the $P$. syringae AvrPphB was shown to cleave an Arabidopsis Ser/Thr protein kinase, PBS1 (139). PBS1 is actually required for the recognition of AvrPphB on resistant plants containing the R protein RPS5 (151). Thus, the recognition of AvrPphB by the RPS5 R protein may depend on the cleavage of PBS1. In support of this notion, plants containing PBS1 mutations that prevent cleavage by AvrPphB no longer recognize AvrPphB (139). 
Recently, the protein structure for AvrPphB has been determined, confirming it to be a papain-like cysteine protease (175). Another exciting finding is that the P. syringae effector AvrRpt 2 initiates (either directly or indirectly) the elimination of the Arabidopsis RIN4 protein, which has been suggested to be a regulator of basal defenses $(15,105,106)$. AvrRpt 2 has a putative cysteine protease catalytic triad, which is required for elimination of RIN4 (14). The discovery of PBS1 and RIN4 as plant targets of AvrPphB and AvrRpt2, respectively, has added much to our understanding of the recognition events occurring in resistant plants, as is discussed further below.

One distinction that may be useful in categorizing TTSS effectors is whether they modify components of plant signal transduction pathways in a potentially reversible manner or simply destroy them. For example, the XopD cysteine protease noted above removes SUMO groups from plant proteins, and these presumably could be re-SUMOlyated at a later point by a native plant protein. Another example of an effector that appears to reversibly modify a plant target is HopPtoD2. This $P$. syringae effector possesses protein tyrosine phosphatase (PTP) activity $(26,53)$. PTPs can inactivate proteins phosphorylated at tyrosine. Since plants do not have many known tyrosine kinases, the most likely targets of HopPtoD2 are MAPK pathways, and plant PTPs are likely involved in regulating these pathways. Similarly, both the P. syringae AvrB and AvrRpm1 effectors were shown to cause the phosphorylation of the RIN4 protein (106). However, the protein structure of AvrB recently has been determined and it does not resemble any known kinase (99). Thus, AvrB may cause RIN4 phosphorylation in an indirect manner.

Another interesting new set of effectors from $P$. syringae are HopPtoS1 (HopPtoO), HopPtoS2, and HopPtoS3 (HopPtoO2), all of which have apparent ADP ribosyltransferase (ART) active sites. The animal pathogen $P$. aeruginosa translocates ARTs via a TTSS into mammalian cells where they target a signal transduction pathway that modulates actin polymerization, thus preventing phagocytosis $(63,150)$. It will be interesting to compare the ART targets in plants and animals. Identifying the plant targets of all of the bacterial plant TTSS effectors will give a better understanding of plant pathogenesis, but a second likely benefit will be new tools for plant biologists exploring signaling networks.

\section{Localization of Effectors in Plant Cells}

The proper functioning of TTSS effectors is also likely to involve colocalization with targets within the host cell. Several P. syringae effectors (AvrB, AvrPphB, AvrPto, AvrRpm1, and AvrRpt2) have been shown to carry myristoylation signals and/or to localize to the plasma membrane $(15,116,138)$. Putative myristoylation sites have been noted in other P. syringae effectors (e.g., HopPtoS1, HopPtoF, and AvrC) $(70,110,128)$. In fact, based on their putative cleavage sites, it appears that the whole YopT/AvrPphB family of effectors in bacterial plant pathogens have putative myristoylation sites. Therefore, it is clear that the plasma membrane is 
a major site of action for phytopathogen effectors. In the cases of AvrRpt 2 and AvrPphB, their respective targets, RIN4 and PBS1, also are localized to the plasma membrane $(15,139)$.

Another destination for some phytopathogen TTSS effectors is the plant nucleus. The AvrBs3 and YopJ/P/AvrBsT families have members that localize to the nucleus $(49,73,161,172)$. The mechanisms for nuclear import may differ among effectors. For example, members of the AvrBs3 family carry nuclear localization signals (NLS) $(161,172)$. Pepper importin $\alpha$ interacted with the NLS sequences of AvrBs3 in a yeast two-hybrid analysis (153), and this host protein, along with importin $\beta$, is involved in directing eukaryotic proteins to the nucleus. In contrast, the PopP2 effector appears to help direct the R protein RRS-1 to the nucleus because RRS-1 is only nuclear-localized in the presence of PopP2 (49). Other TTSS effectors have been predicted to localize to the chloroplast of plant cells (70). Determining where other TTSS effectors localize within plant cells is another systematic method for exploring their function.

\section{Virulence Phenotypes and Effectors as Double Agents}

A subset of phytopathogen effectors is known to promote virulence in compatible interactions, and the list is likely to grow with the development of more subtle assays for mutant phenotypes $(16,90,170)$. Interestingly, some effectors can promote lesion formation in susceptible hosts without a commensurate effect on bacterial growth. These include members of the AvrBs3/PthA family and HopPtoM $(17,171)$. HopPtoM is encoded in the conserved effector locus of $P$. syringae, which is linked to the hrp/hrc cluster. HopPtoN is another effector encoded in this region in $P$. syringae pv. tomato DC3000, which has the opposite effect on lesion formation in host tomato: a hopPtoN mutant produces more necrotic lesions than does wild-type DC3000 (102). But in neither the hopPtoM nor the hopPtoN mutant is there a commensurate effect on bacterial growth. Bacterial growth in planta peaks at approximately the same time and level for the two mutants and the wild-type, regardless of the severity of the lesion symptoms. One interpretation is that disease lesions represent a "delayed HR" resulting from delayed (or suppressed) recognition of HopPtoM and that suppressors like HopPtoN can further delay such defensive recognition. This scenario is consistent with the double agent abilities of many effectors and with the observed similarity in gene expression profiles of Arabidopsis plants at the time plant cells are dying in both compatible and incompatible $P$. syringae interactions (158).

Experiments with AvrPtoB in P. syringae pv. tomato DC3000 yielded a novel example of an effector acting as a double agent in promoting pathogenesis. AvrPtoB is able to suppress programmed cell death in tomato plants lacking the Pto resistance gene (1). However, AvrPtoB possesses an $\mathrm{N}$-terminal domain that can elicit the HR in these otherwise susceptible tomato plants and a C-terminal domain that is required to suppress the HR triggered by the N-terminal domain. Thus, a DC3000 mutant that produces only the N-terminal domain of AvrPtoB is avirulent 
on tomato unless complemented with full-length AvrPtoB (1). It is noteworthy that several of the effectors recently demonstrated to have HR suppressor activity are members of effector families that were previously shown to have avirulence activity (79). Thus, many effectors may be double agents, and whether their elicitor or suppressor activity prevails will depend on the complement of R proteins in the host, on the complement of effectors in the bacterium, and most likely also on quantitative factors associated with the timing and level of delivery relative to other effectors.

\section{Effectors in the Context of Bacterium-Plant Coevolution and the Guard Hypothesis}

A plausible scenario for the evolution of phytopathogen TTSS effector systems follows from considering plant basal defenses and HR defenses, the guard hypothesis (explained below), and the substantial subset of effectors now shown to have suppressor activity. The model predicts four stages in coevolution: $(a)$ Basal defenses that are arrayed against all microbes were likely the first target of the primordial TTSS effectors (92). (b) These effectors (or more likely their activity, according to the guard hypothesis) would have come under the surveillance of the $\mathrm{R}$ protein system and the much stronger HR defense, which is normally triggered only by avirulent pathogens. (c) The HR defenses themselves would then become targets of a later generation of defense-suppressive effectors. $(d)$ Continued coevolution of these pathosystems would generate populations of partners that are highly polymorphic in their respective $\mathrm{R}$ gene and effector gene arsenals, and outcomes would be determined by a matrix of effector-target-guard interactions involving pathogen effectors that may be both elicitors and suppressors and plant proteins that may be both susceptibility targets and defense system hair-triggers.

The guard hypothesis, which is central to this model, was proposed six years ago to explain how the prevalent class of NBS-LRR R proteins recognize Avr proteins $(47,162)$. Instead of the long-standing model that proposed $\mathrm{R}$ proteins recognize Avr proteins directly as ligands (62), the guard hypothesis proposed that R proteins protect or "guard" susceptibility factors that are targeted by pathogen effectors. Thus, $\mathrm{R}$ proteins detect effector-induced modifications and respond by triggering HR defenses. There are several excellent recent reviews that further explain the guard hypothesis and its limitations $(24,84,115,126)$.

Recent evidence in support of the guard hypothesis includes the finding that Avr proteins that were identified as cysteine proteases are dependent on the invariant amino acids of their active sites to be recognized by their cognate $\mathrm{R}$ proteins (122, 140). This suggests that each $\mathrm{R}$ protein is recognizing an enzymatic product of its Avr protein rather than the Avr protein directly. Also supporting the guard hypothesis are the findings discussed above that the targets for both AvrPphB and AvrRpt2 (PBS1 and RIN4) interact with their cognate R proteins, RPS5 and RPS2. That is, PBS1 interacts with the RPS5 R protein and recognition of AvrPphB by RPS5 depends on cleavage of PBS1 by AvrPphB (139). Thus, PBS1 appears to be 
a virulence target of the AvrPphB cysteine protease, and RPS5 appears to closely monitor or "guard" PBS1.

Similarly, AvrRpt 2 causes the elimination of RIN4, the apparent virulence target of AvrRpt2, and elimination of RIN4 triggers RPS2-mediated defenses $(15,105)$. In these cases, for the guard hypothesis to be correct, both RIN4 and PBS1 would need to play a role in compatible interactions in basal defense or some other process whose thwarting would benefit the pathogen. Thus, exploring the roles of PBS1 and RIN4 in defense should help determine whether the guard hypothesis is correct. It is interesting to note that a consequence of the elimination of RIN4 by AvrRpt 2 is disrupted detection of AvrRpm1 and AvrB by the RPM1 R protein and suppression of the RPM1-dependent HR $(15,105)$. Thus, one of the strategies in pathogen coevolution in the face of guarded targets may have been the development of effectors that take out the guard. In the world of double agents, the possibilities for molecular subterfuge seem endless.

\section{CONCLUSIONS: BRINGING DOUBLE AGENTS TO TRIAL}

An important lesson from recent work with TTSS effectors is that the action of these proteins in bacterium-plant interactions is so stealthy and complex that no single experimental trial is likely to expose their multiple functions. Rather, a combination of approaches will be needed. Genomics is a powerful tool here because it enables identification of near-complete sets of effectors for given pathogens, defines effector families, and supports the identification of motifs and structural features predictive of function. Because effectors may be acting in concert and have multiple functions, assays that survey the complete collection of effectors for multiple phenotypes will be important.

We now know that the dossier for each effector in the collection should include information on existence of cognate chaperones, levels of expression and translocation during infection, subcellular localization in planta, and loss-of-function and gain-of-function assays for defense suppression activity and effects on colony initiation, growth, and symptom production. The latter tests should involve plants that are wild-type and compromised in diagnostic defense pathways. Surveys for biochemical function include assays for enzymatic activities, effector modification in planta, identification of interacting plant proteins (and modifications to them), and determination of the protein structures of effectors.

Deeper investigations of individual effectors will yield insights into effector function and, importantly, serve as foundries for the development of new assays with which to survey all effectors. Important questions to address immediately are what assays will most usefully differentiate the suppressive activities of some effectors regarding basal and HR defenses, and how are assay results influenced by great differences in the levels at which effectors are delivered in systems varying from natural infections to transformed plants with strongly expressed transgenes. For example, levels of expression may affect the localization of effectors if binding sites at the target location are limiting $(15,81)$. Thus, the possibility that effectors 
localized to the plasma membrane may be specifically targeted to lipid rafts, which concentrate signaling molecules (95), provides one more argument for the development of assays that closely mimic infection conditions. Given the rapid progress being made in identifying and characterizing TTSS effectors, we can expect these molecular double agents to be even more important as tools for exploring the nature of plant disease and defense in the future.

\section{ACKNOWLEDGMENTS}

Work in the authors' labs was supported by NSF Plant Genome Research Program Cooperative Agreement DBI-0077622 (A.C. and J.R.A.), NSF grant MCB9982646 (A.C.), NSF grant MCB-0317165 (J.R.A.), and USDA/NRI grant 03-35319-13862 (J.R.A.).

\section{The Annual Review of Phytopathology is online at http://phyto.annualreviews.org}

\section{LITERATURE CITED}

1. Abramovitch RB, Kim YJ, Chen S, Dickman MB, Martin GB. 2003. Pseudomonas type III effector AvrPtoB induces plant disease susceptibility by inhibition of host programmed cell death. ЕМВО J. 22:60-69

2. Ahmad M, Majerczak DR, Pike S, Hoyos ME, Novacky A, Coplin DL. 2001. Biological activity of harpin produced by Pantoea stewartii subsp stewartii. Mol. Plant-Microbe Interact. 14:1223-34

3. Alfano JR, Charkowski AO, Deng WL, Badel JL, Petnicki-Ocwieja T, et al. 2000. The Pseudomonas syringae $\mathrm{Hrp}$ pathogenicity island has a tripartite mosaic structure composed of a cluster of type III secretion genes bounded by exchangeable effector and conserved effector loci that contribute to parasitic fitness and pathogenicity in plants. Proc. Natl. Acad. Sci. USA 97:4856-61

4. Alfano JR, Collmer A. 1997. The type III (Hrp) secretion pathway of plant pathogenic bacteria: trafficking harpins, Avr proteins, and death. J. Bacteriol. 179:5655-62

5. Alfano JR, Guo M. 2003. The Pseudomonas syringae Hrp (type III) protein secretion system: advances in the new millenium. See Ref. 143a, pp. 22758

6. Alonso A, Bottini N, Bruckner S, Rahmouni S, Williams S, et al. 2004. Lck dephosphorylation at Tyr-394 and inhibition of $\mathrm{T}$ cell antigen receptor signaling by Yersinia phosphatase YopH. J. Biol. Chem. 279:4922-28

7. Anderson DM, Fouts DE, Collmer A, Schneewind O. 1999. Reciprocal secretion of proteins by the bacterial type III machines of plant and animal pathogens suggests universal recognition of mRNA targeting signals. Proc. Natl. Acad. Sci. USA 96:12839-43

8. Anderson DM, Schneewind O. 1997. A mRNA signal for the type III secretion of Yop proteins by Yersinia enterocolitica. Science 278:1140-43

9. Arlat M, Van Gijsegem F, Huet JC, Pernollet JC, Boucher CA. 1994. PopA1, a protein which induces a hypersensitivelike response on specific Petunia genotypes, is secreted via the Hrp pathway of Pseudomonas solanacearum. EMBO J. 13:543-53

10. Arnold DL, Jackson RW, Fillingham AJ, Goss SC, Taylor JD, et al. 2001. Highly conserved sequences flank 
avirulence genes: isolation of novel avirulence genes from Pseudomonas syringae pv. pisi. Microbiology 147:117182

11. Arnold DL, Pitman A, Jackson RW. 2003. Pathogenicity and other genomic islands in plant pathogenic bacteria. $\mathrm{Mol}$. Plant Pathol. 4:407-20

12. Asai T, Tena G, Plotnikova J, Willmann MR, Chiu WL, et al. 2002. MAP kinase signalling cascade in Arabidopsis innate immunity. Nature 415:977-83

13. Astua-Monge G, Minsavage GV, Stall RE, Davis MJ, Bonas U, Jones JB. 2000. Resistance of tomato and pepper to T3 strains of Xanthomonas campestris pv. vesicatoria is specified by a plantinducible avirulence gene. Mol. PlantMicrobe Interact. 13:911-21

14. Axtell MJ, Chisholm ST, Dahlbeck D, Staskawicz BJ. 2003. Genetic and molecular evidence that the Pseudomonas syringae type III effector protein AvrRpt2 is a cysteine protease. Mol. Microbiol. 49:1537-46

15. Axtell MJ, Staskawicz BJ. 2003. Initiation of RPS2-specified disease resistance in Arabidopsis is coupled to the AvrRpt2-directed elimination of RIN4. Cell 112:369-77

16. Badel JL, Charkowski AO, Deng WL, Collmer A. 2002. A gene in the Pseudomonas syringae pv. tomato Hrp pathogenicity island conserved effector locus, hopPtoA1, contributes to efficient formation of bacterial colonies in planta and is duplicated elsewhere in the genome. Mol. Plant-Microbe Interact. 15:1014-24

17. Badel JL, Nomura K, Bandyopadhyay S, Shimizu R, Collmer A, He SY. 2003. Pseudomonas syringae pv. tomato DC3000 HopPtoM (CEL ORF3) is important for lesion formation but not growth in tomato and is secreted and translocated by the Hrp type III secretion system in a chaperone-dependent manner. Mol. Microbiol. 49:1239-51
18. Baron-Epel O, Gharyal PK, Schindler M. 1988. Pectins as mediators of wall porosity in soybean cells. Planta 175:389-95

19. Bartsev AV, Deakin WJ, Boukli NM, McAlvin CB, Stacey G, et al. 2004. NopL, an effector protein of Rhizobium sp. NGR234, thwarts activation of plant defense reactions. Plant Physiol. 134:871-79

20. Bestwick CS, Bennett MH, Mansfield JW. 1995. hrp mutant of Pseudomonas syringae pv. phaseolicola induces cell wall alterations but not membrane damage leading to the hypersensitive reaction in lettuce. Plant Physiol. 108:503-16

21. Blocker A, Komoriya K, Aizawa S. 2003. Type III secretion systems and bacterial flagella: Insights into their function from structural similarities. Proc. Natl. Acad. Sci. USA 100:3027-30

22. Boch J, Joardar V, Gao L, Robertson TL, Lim M, Kunkel BN. 2002. Identification of Pseudomonas syringae genes induced during infection of Arabidopsis thaliana. Mol. Microbiol. 44:73-88

23. Bogdanove AJ, Beer SV, Bonas U, Boucher CA, Collmer A, et al. 1996. Unified nomenclature for broadly conserved hrp genes of phytopathogenic bacteria. Mol. Microbiol. 20:681-83

24. Bonas U, Lahaye T. 2002. Plant disease resistance triggered by pathogenderived molecules: refined models of specific recognition. Curr. Opin. Microbiol. 5:44-50

25. Boyd AP, Lambermont I, Cornelis GR. 2000. Competition between the Yops of Yersinia enterocolitica for delivery into eukaryotic cells: role of the SycE chaperone binding domain of YopE. J. Bacteriol. 182:4811-21

26. Bretz JR, Mock NM, Charity JC, Zeyad S, Baker CJ, Hutcheson SW. 2003. A translocated protein tyrosine phosphatase of Pseudomonas syringae pv. tomato DC3000 modulates plant defence response to infection. Mol. Microbiol. 49:389-400 
27. Brown I, Mansfield J, Bonas U. 1995. hrp genes in Xanthomonas campestris pv. vesicatoria determine ability to suppress papilla deposition in pepper mesophyll cells. Mol. Plant-Microbe Interact. 8:825-36

28. Buell CR, Joardar V, Lindeberg M, Selengut J, Paulsen IT, et al. 2003. The complete sequence of the Arabidopsis and tomato pathogen Pseudomonas syringae pv. tomato DC3000. Proc. Natl. Acad. Sci. USA 100:10181-86

29. Buttner D, Bonas U. 2002. Getting across-bacterial type III effector proteins on their way to the plant cell. EMBO J. 21:5313-22

30. Buttner D, Bonas U. 2002. Port of entry - the type III secretion translocon. Trends Microbiol. 10:186-92

31. Buttner D, Bonas U. 2003. Common infection strategies of plant and animal pathogenic bacteria. Curr. Opin. Plant Biol. 6:312-19

32. Buttner D, Nennstiel D, Klusener B, Bonas U. 2002. Functional analysis of $\mathrm{HrpF}$, a putative type III translocon protein from Xanthomonas campestris pv. vesicatoria. J. Bacteriol. 184:2389-98

33. Buttner D, Noel L, Thieme F, Bonas U. 2003. Genomic approaches in Xanthomonas campestris pv. vesicatoria allow fishing for virulence genes. $J$. Biotechnol. 106:203-14

34. Casper-Lindley C, Dahlbeck D, Clark ET, Staskawicz BJ. 2002. Direct biochemical evidence for type III secretiondependent translocation of the AvrBs2 effector protein into plant cells. Proc. Natl. Acad. Sci. USA 99:8336-41

35. Chang JH, Goel AK, Grant SR, Dangl JL. 2004. Wake of the flood: ascribing functions to the wave of type III effector proteins of phytopathogenic bacteria. Curr. Opin. Microbiol. 7:11-18

36. Charity JC, Pak K, Delwiche CF, Hutcheson SW. 2003. Novel exchangeable effector loci associated with the Pseudomonas syringae hrp pathogenicity island: evidence for integron-like assembly from transposed gene cassettes. Mol. Plant-Microbe Interact. 16:496-507

37. Charkowski AO, Alfano JR, Preston G, Yuan J, He SY, Collmer A. 1998. The Pseudomonas syringae pv. tomato HrpW protein has domains similar to harpins and pectate lyases and can elicit the plant hypersensitive response and bind to pectate. J. Bacteriol. 180:5211-17

38. Chatterjee A, Cui Y, Chatterjee AK. 2002. Regulation of Erwinia carotovora $\operatorname{hrpL}_{\mathrm{Ecc}}$ (sigma- $\mathrm{L}_{\mathrm{Ecc}}$ ), which encodes an extracytoplasmic function subfamily of sigma factor required for expression of the HRP regulon. Mol. Plant-Microbe Interact. 15:971-80

39. Chen Z, Kloek AP, Cuzick A, Moeder W, Tang D, et al. 2004. The Pseudomonas syringae type III effector AvrRpt2 functions downstream or independently of SA to promote virulence on Arabidopsis thaliana. Plant J. 37:494-504

40. Cheng LW, Anderson DM, Schneewind O. 1997. Two independent type III secretion mechanisms for YopE in Yersinia enterocolitica. Mol. Microbiol. 24:75765

41. Collmer A, Lindeberg M, PetnickiOcwieja T, Schneider DJ, Alfano JR. 2002. Genomic mining type III secretion system effectors in Pseudomonas syringae yields new picks for all TTSS prospectors. Trends Microbiol. 10:46269

42. Cornelis GR. 2000. Molecular and cell biology aspects of plague. Proc. Natl. Acad. Sci. USA 97:8778-83

43. Cornelis GR. 2002. Yersinia type III secretion: send in the effectors. J. Cell Biol. 158:401-8

44. Cornelis GR. 2002. The Yersinia YscYop 'type III' weaponry. Nat. Rev. Mol. Cell Biol. 3:742-52

45. Cornelis GR, Van Gijsegem F. 2000. Assembly and function of type III secretory systems. Annu. Rev. Microbiol. 54:73574 
46. Da Silva AC, Ferro JA, Reinach FC, Farah CS, Furlan LR, et al. 2002. Comparison of the genomes of two Xanthomonas pathogens with differing host specificities. Nature 417:459-63

47. Dangl JL, Jones JD. 2001. Plant pathogens and integrated defence responses to infection. Nature 411:826-33

48. Deng W-L, Rehm A, Charkowski A, Rojas CM, Collmer A. 2003. Pseudomonas syringae exchangeable effector loci: sequence diversity in representative pathovars and virulence function in $P$. syringae pv. syringae B728a. J. Bacteriol. 185:2592-602

49. Deslandes L, Olivier J, Peeters N, Feng DX, Khounlotham M, et al. 2003. Physical interaction between RRS1-R, a protein conferring resistance to bacterial wilt, and PopP2, a type III effector targeted to the plant nucleus. Proc. Natl. Acad. Sci. USA 100:8024-29

50. Dong H, Delaney TP, Bauer DW, Beer SV. 1999. Harpin induces disease resistance in Arabidopsis through the systemic acquired resistance pathway mediated by salicylic acid and the NIMI gene. Plant J. 20:207-15

51. Dow M, Newman MA, von Roepenack E. 2000. The induction and modulation of plant defense responses by bacterial lipopolysaccharides. Annu. Rev. Phytopathol. 38:241-61

52. Duan YP, Castaneda A, Zhao G, Erdos G, Gabriel DW. 1999. Expression of a single, host-specific, bacterial pathogenicity gene in plant cells elicits division, enlargement, and cell death. Mol. PlantMicrobe Interact. 12:556-60

53. Espinosa A, Guo M, Tam VC, Fu ZQ, Alfano JR. 2003. The Pseudomonas syringae type III-secreted protein HopPtoD2 possesses protein tyrosine phosphatase activity and suppresses programmed cell death in plants. Mol. Microbiol. 49:377-87

54. Eulgem T, Rushton PJ, Robatzek S, Somssich IE. 2000. The WRKY superfamily of plant transcription factors. Trends Plant Sci. 5:199-206

55. Ezra D, Barash I, Weinthal DM, Gaba V, Manulis S. 2004. pth $G$ from Pantoea agglomerans pv. gypsophilae encodes an avirulence effector that determines incompatibility in multiple beet species. Mol. Plant Pathol. 5:105-13

56. Feldman MF, Cornelis GR. 2003. The multitalented type III chaperones: all you can do with $15 \mathrm{kDa}$. FEMS Microbiol. Lett. 219:151-58

57. Felix G, Boller T. 2003. Molecular sensing of bacteria in plants. The highly conserved RNA-binding motif RNP-1 of bacterial cold shock proteins is recognized as an elicitor signal in tobacco. $J$. Biol. Chem. 278:6201-8

58. Felix G, Duran JD, Volko S, Boller T. 1999. Plants have a sensitive perception system for the most conserved domain of bacterial flagellin. Plant J. 18:265-76

59. Fouts DE, Abramovitch RB, Alfano JR, Baldo AM, Buell CR, et al. 2002. Genomewide identification of Pseudomonas syringae pv. tomato DC3000 promoters controlled by the HrpL alternative sigma factor. Proc. Natl. Acad. Sci. USA 99:2275-80

60. Fouts DE, Badel JL, Ramos AR, Rapp RA, Collmer A. 2003. A Pseudomonas syringae pv. tomato DC3000 Hrp (type III secretion) deletion mutant expressing the Hrp system of bean pathogen $P$. syringae pv. syringae 61 retains normal host specificity for tomato. Mol. PlantMicrobe Interact. 16:43-52

61. Francis MS, Wolf-Watz H, Forsberg A. 2002. Regulation of type III secretion systems. Curr. Opin. Microbiol. 5:16672

62. Gabriel DW, Rolfe BG. 1990. Working models of specific recognition in plantmicrobe interactions. Annu. Rev. Phytopathol. 28:365-91

63. Ganesan AK, Mende-Mueller L, Selzer J, Barbieri JT. 1999. Pseudomonas aeruginosa exoenzyme $\mathrm{S}$, a double 
ADP-ribosyltransferase, resembles vertebrate mono-ADP-ribosyltransferases. J. Biol. Chem. 274:9503-8

64. Gaudriault S, Paulin JP, Barny MA. 2002. The $\mathrm{DspB} / \mathrm{F}$ protein of Erwinia amylovora is a type III secretion chaperone ensuring efficient intrabacterial production of the Hrp-secreted DspA/E pathogenicity factor. Mol. Plant Pathol. 3:313-20

65. Gomez-Gomez L, Boller T. 2000. FLS2: an LRR receptor-like kinase involved in the perception of the bacterial elicitor flagellin in Arabidopsis. Mol. Cell 5:1003-11

66. Gomez-Gomez L, Boller T. 2002. Flagellin perception: a paradigm for innate immunity. Trends Plant Sci. 7:251-56

67. Greenberg JT, Vinatzer BA. 2003. Identifying type III effectors of plant pathogens and analyzing their interaction with plant cells. Curr. Opin. Microbiol. 6:2028

68. Gueneron M, Timmers AC, Boucher C, Arlat M. 2000. Two novel proteins, PopB, which has functional nuclear localization signals, and PopC, which has a large leucine-rich repeat domain, are secreted through the hrp-secretion apparatus of Ralstonia solanacearum. Mol. Microbiol. 36:261-77

69. Guttman DS, Sarkar SF. 2003. Evolutionary and functional genomics of host specificity in Pseudomonas syringae. In Int. Congr. Mol. Plant-Microbe Interact. St. Petersberg, Russia. In press

70. Guttman DS, Vinatzer BA, Sarkar SF, Ranall MV, Kettler G, Greenberg JT. 2002. A functional screen for the Type III (Hrp) secretome of the plant pathogen Pseudomonas syringae. Science 295:1722-26

71. Hauck P, Thilmony R, He SY. 2003. A Pseudomonas syringae type III effector suppresses cell wall-based extracellular defense in susceptible Arabidopsis plants. Proc. Natl. Acad. Sci. USA 100:8577-82
72. He SY, Jin Q. 2003. The Hrp pilus: learning from flagella. Curr. Opin. Microbiol. 6:15-99

73. Hotson A, Chosed R, Shu H, Orth K, Mudgett MB. 2003. Xanthomonas type III effector XopD targets SUMOconjugated proteins in planta. Mol. $\mathrm{Mi}$ crobiol. 50:377-89

74. Innes R. 2003. New effects of type III effectors. Mol. Microbiol. 50:363-65

75. Iriarte M, Cornelis GR. 1998. YopT, a new Yersinia Yop effector protein, affects the cytoskeleton of host cells. Mol. Microbiol. 29:915-29

76. Jackson RW, Athanassopoulos E, Tsiamis G, Mansfield JW, Sesma A, et al. 1999. Identification of a pathogenicity island, which contains genes for virulence and avirulence, on a large native plasmid in the bean pathogen Pseudomonas syringae pathovar phaseolicola. Proc. Natl. Acad. Sci. USA 96:10875-80

77. Jakobek JL, Lindgren PB. 1993. Generalized induction of defense responses in bean is not correlated with the induction of the hypersensitive reaction. Plant Cell 5:49-56

78. Jakobek JL, Smith JA, Lindgren PB. 1993. Suppression of bean defense responses by Pseudomonas syringae. Plant Cell 5:57-63

79. Jamir Y, Guo M, Oh H-S, PetnickiOcwieja T, Chen S, Tang X, et al. 2004. Identification of Pseudomonas syringae type III secreted effectors that suppress programmed cell death in plants and yeast. Plant J. 37:554-65

80. Jamir Y, Tang X, Alfano JR. 2004. The genome of Pseudomonas syringae pv. tomato DC3000 and functional genomic studies to better understand plant pathogenesis. In Pseudomonas, Vol. 1: Genomics, Life Style and Molecular Architecture, ed. JL Ramos. London: Kluwer/Plenum. In press

81. Jin P, Wood MD, Wu Y, Xie ZY, Katagiri F. 2003. Cleavage of the Pseudomonas syringae type III effector AvrRpt2 
requires a host factor(s) common among eukaryotes and is important for AvrRpt2 localization in the host cell. Plant Physiol. 133:1072-82

82. Jin Q, He SY. 2001. Role of the Hrp pilus in type III protein secretion in $\mathrm{Pseu}$ domonas syringae. Science 294:255658

83. Jin Q, Hu W, Brown I, McGhee G, Hart P, et al. 2001. Visualization of secreted Hrp and Avr proteins along the Hrp pilus during type III secretion in Erwinia amylovora and Pseudomonas syringae. Mol. Microbiol. 40:1129-39

84. Jones DA, Takemoto D. 2004. Plant innate immunity-direct and indirect recognition of general and specific pathogen-associated molecules. Curr. Opin. Immunol. 16:48-62

85. Kanda A, Yasukohchi M, Ohnishi K, Kiba A, Okuno T, Hikichi Y. 2003. Ectopic expression of Ralstonia solanacearum effector protein PopA early in invasion results in loss of virulence. Mol. Plant-Microbe Interact. 16:44755

86. Keen NT. 1990. Gene-for-gene complementarity in plant-pathogen interactions. Annu. Rev. Genet. 24:447-63

87. Kim JF, Alfano JR. 2002. Pathogenicity islands and virulence plasmids of bacterial plant pathogens. Curr. Top. Microbiol. Immunol. 264:127-47

88. Kim JF, Beer SV. 1998. HrpW of Erwinia amylovora, a new harpin that contains a domain homologous to pectate lyases of a distinct class. J. Bacteriol. 180:5203510

89. Kim JG, Park BK, Yoo CH, Jeon E, Oh J, Hwang I. 2003. Characterization of the Xanthomonas axonopodis pv. glycines Hrp pathogenicity island. J. Bacteriol. 185:3155-66

90. Kjemtrup S, Nimchuk Z, Dang1 JL. 2000. Effector proteins of phytopathogenic bacteria: bifunctional signals in virulence and host recognition. Curr. Opin. Microbiol. 3:73-78
91. Klement Z. 1982. Hypersensitivity. In Phytopathogenic Prokaryotes, ed. MS Mount, GH Lacy, 2:149-77. New York: Academic

92. Klement Z, Bozso Z, Besenyei E, Czelleng A, Kecskes ML, Ott PG. 2003. Early induced resistance, a general, symptomless plant response to bacteria. In Pseudomonas syringae and Related Pathogens: Biology and Genetics, ed. NS Iacobellis, A Collmer, SW Hutcheson, JW Mansfield, CE Morris, et al., pp. 3019. Dordrecht: Kluwer

93. Klement Z, Bozso Z, Kecskes ML, Besenyei E, Arnold C, Ott PG. 2003. Local early induced resistance of plants as the first line of defence against bacteria. Pest Manag. Sci. 59:465-74

94. Kobayashi DY, Tamaki SJ, Keen NT. 1989. Cloned avirulence genes from the tomato pathogen Pseudomonas syringae pv. tomato confer cultivar specificity on soybean. Proc. Natl. Acad. Sci. USA 86: 157-61

95. Lafont F, Abrami L, van der Goot FG. 2004. Bacterial subversion of lipid rafts. Curr. Opin. Microbiol. 7:4-10

96. Lahaye T, Bonas U. 2001. Molecular secrets of bacterial type III effector proteins. Trends Plant Sci. 6:47985

97. Lavie M, Shillington E, Eguiluz C, Grimsley N, Boucher C. 2002. PopP1, a new member of the YopJ/AvrRxv family of type III effector proteins, acts as a host-specificity factor and modulates aggressiveness of Ralstonia solanacearum. Mol. Plant-Microbe Interact. 15:105868

98. Lee J, Klusener B, Tsiamis G, Stevens C, Neyt C, et al. 2001. HrpZ Psph $_{\text {from the }}$ plant pathogen Pseudomonas syringae pv. phaseolicola binds to lipid bilayers and forms an ion-conducting pore in vitro. Proc. Natl. Acad. Sci. USA 98:28994

99. Lee SH, Galan JE. 2004. Salmonella type III secretion-associated chaperones 
confer secretion-pathway specificity. Mol. Microbiol. 51:483-95

100. Li CM, Brown I, Mansfield J, Stevens C, Boureau T, et al. 2002. The Hrp pilus of Pseudomonas syringae elongates from its tip and acts as a conduit for translocation of the effector protein HrpZ. EMBO J. 21:1909-15

101. Lincoln JE, Richael C, Overduin B, Smith K, Bostock R, Gilchrist DG. 2002. Expression of the antiapoptotic baculovirus p35 gene in tomato blocks programmed cell death and provides broadspectrum resistance to disease. Proc. Natl. Acad. Sci. USA 99:15217-21

102. López-Solanilla E, Bronstein PA, Schneider AR, Collmer A. 2004. HopPtoN is a Pseudomonas syringae TTSS effector and cysteine protease that suppresses pathogen-induced necrosis associated with both compatible and incompatible plant interactions. Mol. Microbiol. Submitted

103. Lorang JM, Shen H, Kobayashi D, Cooksey D, Keen NT. 1994. avrA and $a v r E$ in Pseudomonas syringae pv. tomato PT23 play a role in virulence on tomato plants. Mol. Plant-Microbe Interact. 7:508-15

104. Losada L, Sussan T, Pak K, Zeyad S, Rozenbaum I, Hutcheson SW. 2004. Identification of a novel Pseudomonas syringae Psy61 effector with virulence and avirulence functions by a HrpLdependent promoter-trap assay. Mol. Plant-Microbe Interact. 17:254-62

105. Mackey D, Belkhadir Y, Alonso JM, Ecker JR, Dangl JL. 2003. Arabidopsis RIN4 is a target of the type III virulence effector AvrRpt 2 and modulates RPS2mediated resistance. Cell 112:379-89

106. Mackey D, Holt BF, Wiig A, Dangl JL. 2002. RIN4 interacts with Pseudomonas syringae type III effector molecules and is required for RPM1-mediated resistance in Arabidopsis. Cell 108:743-54

107. Manulis A, Barash I. 2003. Molecular basis for transformation of an epiphyte into a gall-forming pathogen as exempli- fied by Erwinia herbicola pv. gypsophilae. See Reference 143a, pp. 19-52

108. Marois E, Van den Ackerveken G, Bonas U. 2002. The Xanthomonas type III effector protein AvrBs3 modulates plant gene expression and induces cell hypertrophy in the susceptible host. Mol. Plant-Microbe Interact. 15:637-46

109. Martin GB, Bogdanove AJ, Sessa G. 2003. Understanding the functions of plant disease resistance proteins. Annu. Rev. Plant Biol. 54:23-61

110. Maurer-Stroh S, Eisenhaber F. 2004. Myristoylation of viral and bacterial proteins. Trends Microbiol. 12:178-85

111. Medzhitov R, Janeway CA Jr. 2002. Decoding the patterns of self and nonself by the innate immune system. Science 296:298-300

112. Merighi M, Majerczak DR, Stover EH, Coplin DL. 2003. The HrpX/HrpY twocomponent system activates hrpS expression, the first step in the regulatory cascade controlling the Hrp regulon in Pantoea stewartii subsp. stewartii. Mol. Plant-Microbe Interact. 16:238-48

113. Midland SL, Keen NT, Sims JJ, Midland MM, Stayton MM, et al. 1993. The structures of syringolides 1 and 2: novel $\mathrm{C}$ glycosidic elicitors from $\mathrm{Pseu}$ domonas syringae pv. tomato. J. Org. Chem. 58:2940-45

114. Mudgett MB, Chesnokova O, Dahlbeck D, Clark ET, Rossier O, et al. 2000. Molecular signals required for type III secretion and translocation of the Xanthomonas campestris AvrBs2 protein to pepper plants. Proc. Natl. Acad. Sci. USA 97:13324-29

115. Nimchuk Z, Eulgem T, Holt BF 3rd, Dangl JL. 2003. Recognition and response in the plant immune system. Annu. Rev. Genet. 37:579-609

116. Nimchuk Z, Marois E, Kjemtrup S, Leister RT, Katagiri F, Dangl JL. 2000. Eukaryotic fatty acylation drives plasma membrane targeting and enhances function of several type III effector proteins 
from Pseudomonas syringae. Cell 101: 353-63

117. Noel L, Thieme F, Gabler J, Buttner D, Bonas U. 2003. XopC and XopJ, two novel type III effector proteins from Xanthomonas campestris pv. vesicatoria. $J$. Bacteriol. 185:7092-102

118. Noel L, Thieme F, Nennstie D, Bonas U. 2001. cDNA-AFLP analysis unravels a genome-wide hrpG-regulon in the plant pathogen Xanthomonas campestris pv. vesicatoria. Mol. Microbiol. 41:1271-81

119. Nurnberger T, Brunner F. 2002. Innate immunity in plants and animals: emerging parallels between the recognition of general elicitors and pathogenassociated molecular patterns. Curr. Opin. Plant Biol. 5:318-24

120. Orth K. 2002. Function of the Yersinia effector YopJ. Curr. Opin. Microbiol. 5:38-43

121. Orth K, Palmer LE, Bao ZQ, Stewart S, Rudolph AE, et al. 1999. Inhibition of the mitogen-activated protein kinase kinase superfamily by a Yersinia effector. Science 285:1920-23

122. Orth K, Xu Z, Mudgett MB, Bao ZQ, Palmer LE, et al. 2000. Disruption of signaling by Yersinia effector YopJ, a ubiquitin-like protein protease. Science 290:1594-97

123. Page AL, Parsot C. 2002. Chaperones of the type III secretion pathway: jacks of all trades. Mol. Microbiol. 46:1-11

124. Parkhill J. 2002. The importance of complete genome sequences. Trends Microbiol. 10:219-20

125. Parsot C, Hamiaux C, Page AL. 2003. The various and varying roles of specific chaperones in type III secretion systems. Curr. Opin. Microbiol. 6:7-14

126. Pedley KF, Martin GB. 2003. Molecular basis of Pto-mediated resistance to bacterial speck disease in tomato. Annu. Rev. Phytopathol. 41:215-43

127. Peng JL, Dong HS, Dong HP, Delaney TP, Bonasera JM, Beer SV. 2003. Harpin-elicited hypersensitive cell death and pathogen resistance require the NDR1 and EDS1 genes. Physiol. Mol. Plant Pathol. 62:317-26

128. Petnicki-Ocwieja T, Schneider DJ, Tam VC, Chancey ST, Shan L, et al. 2002. Genomewide identification of proteins secreted by the Hrp type III protein secretion system of Pseudomonas syringae pv. tomato DC3000. Proc. Natl. Acad. Sci. USA 99:7652-57

129. Preston G, Huang H-C, He SY, Collmer A. 1995. The HrpZ proteins of Pseudomonas syringae pvs. syringae, glycinea, and tomato are encoded by an operon containing Yersinia ysc homologs and elicit the hypersensitive response in tomato but not soybean. Mol. Plant-Microbe Interact. 8:717-32

130. Puri N, Jenner C, Bennett M, Stewart R, Mansfield J, et al. 1997. Expression of avrPphB, an avirulence gene from Pseudomonas syringae pv. phaseolicola, and the delivery of signals causing the hypersensitive reaction in bean. Mol. PlantMicrobe Interact. 10:247-56

131. Reuber TL, Ausubel FM. 1996. Isolation of Arabidopsis genes that differentiate between resistance responses mediated by the RPS 2 and RPM1 disease resistance genes. Plant Cell 8:241-49

132. Ritter C, Dangl JL. 1996. Interference between two specific pathogen recognition events mediated by distinct plant disease resistance genes. Plant Cell 8:25157

133. Rohmer L, Kjemtru S, Marchesin P, Dangl JL. 2003. Nucleotide sequence, functional characterization and evolution of pFKN, a virulence plasmid in Pseudomonas syringae pathovar maculicola. Mol. Microbiol. 47:1545-62

134. Rossier O, Van den Ackerveken G, Bonas U. 2000. HrpB2 and HrpF from Xanthomonas are type III-secreted proteins and essential for pathogenicity and recognition by the host plant. Mol. Microbiol. 38:828-38

135. Salanoubat M, Genin S, Artiguenave 
F, Gouzy J, Mangenot S, et al. 2002. Genome sequence of the plant pathogen Ralstonia solanacearum. Nature 415: 497-502

136. Schechter LM, Roberts KA, Jamir Y, Alfano JR, Collmer A. 2004. Pseudomonas syringae type III secretion system targeting signals and novel effectors studied with a Cya translocation reporter. J. Bacteriol. 186:543-55

137. Shan L, Oh H-S, Guo M, Zhou J, Alfano JR, et al. 2004. The hopPtoF locus of Pseudomonas syringae pv. tomato DC3000 encodes a type III chaperone and a cognate effector. Mol. PlantMicrobe Interact. In press

138. Shan LB, Thara VK, Martin GB, Zhou JM, Tang XY. 2000. The Pseudomonas AvrPto protein is differentially recognized by tomato and tobacco and is localized to the plant plasma membrane. Plant Cell 12:2323-37

139. Shao F, Golstein C, Ade J, Stoutemyer M, Dixon JE, Innes RW. 2003. Cleavage of Arabidopsis PBS1 by a bacterial type III effector. Science 301:1230-33

140. Shao F, Merritt PM, Bao Z, Innes RW, Dixon JE. 2002. A Yersinia effector and a Pseudomonas avirulence protein define a family of cysteine proteases functioning in bacterial pathogenesis. Cell 109:57588

141. Shimizu R, Taguchi F, Marutani M, Mukaihara T, Inagaki Y, et al. 2003. The deltafliD mutant of Pseudomonas syringae pv. tabaci, which secretes flagellin monomers, induces a strong hypersensitive reaction (HR) in non-host tomato cells. Mol. Genet. Genomics 269: 21-30

142. Sorg I, Goehring UM, Aktories K, Schmidt G. 2001. Recombinant Yersinia YopT leads to uncoupling of RhoAeffector interaction. Infect. Immun. 69: 7535-43

143. Sory M-P, Cornelis GR. 1994. Translocation of a hybrid YopE-adenylate cyclase from Yersinia enterocolitica into
HeLa cells. Mol. Microbiol. 14:58394

143a. Stacey G, Keen NT, eds. 2003. PlantMicrobe Interactions, Vol. 6. St. Paul; APS Press

144. Staskawicz BJ, Dahlbeck D, Keen NT, Napoli C. 1987. Molecular characterization of cloned avirulence genes from race 0 and race 1 of Pseudomonas syringae pv. glycinea. J. Bacteriol. 169:5789-94

145. Staskawicz BJ, Dahlbeck D, Keen NT. 1984. Cloned avirulence gene of Pseudomonas syringae pv. glycinea determines race specific incompatibility on Glycine max (L.) Merr. Proc. Natl. Acad. Sci. USA 81:6024-28

146. Stebbins CE, Galan JE. 2001. Maintenance of an unfolded polypeptide by a cognate chaperone in bacterial type III secretion. Nature 414:77-81

147. Stevens C, Bennett MA, Athanassopoulos E, Tsiamis G, Taylor JD, Mansfield JW. 1998. Sequence variations in alleles of the avirulence gene avrPphE.R2 from Pseudomonas syringae pv. phaseolicola lead to loss of recognition of the AvrPphE protein within bean cells and a gain in cultivar-specific virulence. Mol. Microbiol. 29:165-77

148. Stone JM, Heard JE, Asai T, Ausubel FM. 2000. Simulation of fungalmediated cell death by fumonisin B1 and selection of fumonisin B1-resistant (fbr) Arabidopsis mutants. Plant Cell 12:1811-22

149. Strobel NE, Ji C, Gopalan S, Kuc JA, He SY. 1996. Induction of systemic acquired resistance in cucumber by Pseudomonas syringae pv. syringae $61 \mathrm{HrpZ}_{\mathrm{Pss}}$ protein. Plant J. 9:431-39

150. Sun J, Barbieri JT. 2003. Pseudomonas aeruginosa ExoT ADP-ribosylates CT10 regulator of kinase (Crk) proteins. J. Biol. Chem. 278:32794-800

151. Swiderski MR, Innes RW. 2001. The Arabidopsis PBS1 resistance gene encodes a member of a novel protein kinase subfamily. Plant J. 26:101-12 
152. Swords KMM, Dahlbeck D, Kearney B, Roy M, Staskawicz BJ. 1996. Spontaneous and induced mutations in a single open reading frame alters both virulence and avirulence in Xanthomonas campestris pv. vesicatoria avrBs2. J. Bacteriol. 178:4661-69

153. Szurek B, Marois E, Bonas U, Van den Ackerveken G. 2001. Eukaryotic features of the Xanthomonas type III effector AvrBs3: protein domains involved in transcriptional activation and the interaction with nuclear import receptors from pepper. Plant J. 26:523-34

154. Taguchi F, Shimizu R, Inagaki Y, Toyoda K, Shiraishi T, Ichinose Y. 2003. Posttranslational modification of flagellin determines the specificity of HR induction. Plant Cell Physiol. 44:342-49

155. Taguchi F, Shimizu R, Nakajima R, Toyoda K, Shiraishi T, Ichinose Y. 2003. Differential effects of flagellins from Pseudomonas syringae pv. tabaci, tomato and glycinea on plant defense response. Plant Physiol. Biochem. 41:165-74

156. Takeuchi K, Taguchi F, Inagaki Y, Toyoda K, Shiraishi T, Ichinose Y. 2003. Flagellin glycosylation island in Pseudomonas syringaepv. glycinea and its role in host specificity. J. Bacteriol. 185 : 6658-65

157. Tampakaki AP, Panopoulos NJ. 2000. Elicitation of hypersensitive cell death by extracellularly targeted HrpZPsph produced in planta. Mol. Plant-Microbe Interact. 13:1366-74

158. Tao Y, Xie Z, Chen W, Glazebrook J, Chang HS, et al. 2003. Quantitative nature of Arabidopsis responses during compatible and incompatible interactions with the bacterial pathogen $\mathrm{Pseu}$ domonas syringae. Plant Cell 15:317-30

159. Thomas NA, Brett Finlay B. 2003. Establishing order for type III secretion substrates-a hierarchical process. Trends Microbiol. 11:398-403

160. Tsiamis G, Mansfield JW, Hockenhull R, Jackson RW, Sesma A, et al. 2000.
Cultivar-specific avirulence and virulence functions assigned to avrPphF in Pseudomonas syringae pv. phaseolicola, the cause of bean halo-blight disease. EMBO J. 19:3204-14

161. Van den Ackerveken G, Marois E, Bonas U. 1996. Recognition of the bacterial avirulence protein AvrBs3 occurs inside the host plant cell. Cell 87:1307-16

162. Van der Biezen EA, Jones JD. 1998. Plant disease-resistance proteins and the gene-for-gene concept. Trends Biochem. Sci. 23:454-56

163. van Dijk K, Tam VC, Records AR, Petnicki-Ocwieja T, Alfano JR. 2002. The ShcA protein is a molecular chaperone that assists in the secretion of the HopPsyA effector from the type III (Hrp) protein secretion system of Pseudomonas syringae. Mol. Microbiol. 44:1469-81

164. Viboud GI, So SS, Ryndak MB, Bliska JB. 2003. Proinflammatory signalling stimulated by the type III translocation factor YopB is counteracted by multiple effectors in epithelial cells infected with Yersinia pseudotuberculosis. Mol. Microbiol. 47:1305-15

165. Wattiau P, Bernier B, Deslee P, Michiels T, Cornelis GR. 1994. Individual chaperones required for Yop secretion by Yersinia. Proc. Natl. Acad. Sci. USA 91: 10493-97

166. Wattiau P, Woestyn S, Cornelis GR. 1996. Customized secretion chaperones in pathogenic bacteria. Mol. Microbiol. 20:255-62

167. Wehling MD, Guo M, Fu ZQ, Alfano JR. 2004. The Pseudomonas syringae HopPtoV protein is secreted in culture and translocated into plant cells via the type III protein secretion system in a manner dependent on the ShcV type III chaperone. J. Bacteriol. In press

168. Wei Z-M, Beer SV. 1996. Harpin from Erwinia amylovora induces plant resistance. Acta Hortic. 411:223-25

169. Whalen MC, Wang JF, Carland FM, 
Heiskell ME, Dahlbeck D, et al. 1993. Avirulence gene avrRxv from Xanthomonas campestris pv. vesicatoria specifies resistance on tomato line Hawaii 7998. Mol. Plant-Microbe Interact. 6: 616-27

170. White FF, Yang B, Johnson LB. 2000. Prospects for understanding avirulence gene function. Curr. Opin. Plant Biol. 3:291-98

171. Yang Y, DeFeyter R, Gabriel DW. 1994. Host-specific symptoms and increased release of Xanthomonas citri and X. campestris pv. malvacearum from leaves are determined by the $102 \mathrm{bp}$ tandem repeats of pthA and avrb6, respectively. Mol. Plant-Microbe Interact. 7:345-55

172. Yang Y, Gabriel DW. 1995. Xanthomonas avirulence/pathogenicity gene family encodes functional plant nuclear targeting signals. Mol. Plant-Microbe Interact. 8:627-31

173. Yao T, Mecsas J, Healy JI, Falkow S, Chien YH. 1999. Suppression of $\mathrm{T}$ and $\mathrm{B}$ lymphocyte activation by a Yersinia pseudotuberculosis virulence factor, yopH. J. Exp. Med. 190:1343-45

174. Zhang S, Klessig DF. 2001. MAPK cascades in plant defense signaling. Trends Plant Sci. 6:520-27
175. Zhu MF, Shao F, Innes RW, Dixon JE, $\mathrm{Xu} \mathrm{ZH}$, et al. 2004. The crystal structure of Pseudomonas avirulence protein AvrPphB: a papain-like fold with a distinct substrate-binding site. Proc. Natl. Acad. Sci. USA 101:302-7

176. Zhu WG, Mabanua MM, White FF. 2000. Identification of two novel hrpassociated genes in the hrp gene cluster of Xanthomonas oryzae pv. oryzae. J. Bacteriol. 182:1844-53

177. Zhu WG, Yang B, Chittoor JM, Johnson LB, White FF. 1998. AvrXa10 contains an acidic transcriptional activation domain in the functionally conserved $\mathrm{C}$ terminus. Mol. Plant-Microbe Interact. 11:824-32

178. Zhu W, Yang B, Wills N, Johnson LB, White FF. 1999. The C terminus of AvrXa10 can be replaced by the transcriptional activation domain of VP16 from the herpes simplex virus. Plant Cell 11:1665-74

179. Zwiesler-Vollick J, Plovanich-Jones AE, Nomura K, Brandyopadhyay S, Joardar $\mathrm{V}$, et al. 2002. Identification of novel hrp-regulated genes through functional genomic analysis of the Pseudomonas syringae pv. tomato DC3000 genome. Mol. Microbiol. 45:1207-18 